\title{
Awareness of University Library Services and Resources Among Postgraduate Students of Selected Universities of JCtK: A Comparative Assessment
}

\author{
Javaid Ahmad Wani ${ }^{1}$ and Shabir Ahmad Ganaie ${ }^{2}$ \\ ${ }^{1} P h D$ Research Scholar, Department of Library and Information \\ Science, University of Kashmir, Srinagar-India \\ ${ }^{2}$ Department of Library and Information Science, University of \\ Kashmir, Srinagar-India
}

\begin{abstract}
University libraries are vital organs for universities to support academics and research related activities. Effective use of resources and services of any academic library particularly university libraries will enhance the research and academic tasks. These libraries fulfil the information needs of users associated with diverse field of studies. These libraries provide the varied sources of information and different services to the users. The efficiency of academic library depends upon the awareness and familiarity of the users with different services and resources of libraries. Therefore, the current study is an attempt to gauge the awareness of users of selected university libraries, total 4 universities were selected two state universities and two central universities from Jammu and Kashmir. Survey method was adopted to fulfil the objectives of the study and questionnaire was used as a tool for data collection. Sampling method applied was simple random sampling. The sample size was 600, equally selected from 4 universities. Data was tabulated by using widely used statistical tool SPSS. The descriptive as well as inferential statistical tests were followed to test the data, mean, median, standard deviation, comparative analysis was carried out by applying one way Annova statistical test. The major findings of the study were 48 percent library users had visited library frequently. Based on the overall mean of x 1.92 and M 2.00, it can be concluded that the users are well aware about the services of concerned libraries. Further, based on the overall mean of $\mathrm{x} \otimes 1.90$ and M 2.00, it can be concluded that the users are well aware about the resources of the concerned libraries. While applying comparative statistical techniques on mean scores of services and resources it was found that only current awareness service (CAS) and online public access cataloguing (OPAC) awareness were statistically significant (p $<0.05)$. Furthermore, It is evident from the results that all the resource awareness parameters were statistically significant excluding Reference Books Awareness (RBA having P value greater than 0.05 ( $p=0.055>0.05$ ).
\end{abstract}

KEY WORDS: LIBRARY SERVICES, LIBRARY RESOURCES, AWARENESS, UNIVERSITY LIBRARIES, POSTGRADUATE STUDENTS, JETK.

\section{ARTICLE INFORMATION}

Received 11th Oct 2020 Accepted after revision 28th Dec 2020 Print ISSN: 0974-6455 Online ISSN: 2321-4007 CODEN: BBRCBA

Thomson Reuters ISI Web of Science Clarivate Analytics USA and Crossref Indexed Journal

\section{Clarivate
Analytics}

NAAS Journal Score 2020 (4.31)

A Society of Science and Nature Publication,

Bhopal India 2020. All rights reserved.

Online Contents Available at: http//www.bbrc.in/

Doi: $h$ ttp://dx.doi.org/10.21786/bbrc/13.15/39

\section{INTRODUCTION}

In the context of this modern learning system, the university library plays an important role. According to this modern definition of study, as a subsystem of the university institution, the university library was no longer a section that simply offered resources for studies and analysis. Instead, it has been an important knowledge technology entity of the university and an

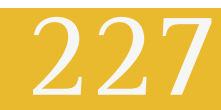


involved partner in the research phase of the relevant study programme. The academic library aims to realise the goals along with the university departments and teaching staff. One of the possible learning spaces at the university is the library. The academic library provides learning environment in an individualised learning setting and consists of the instructional setting of the library that an individual reader describes related to his or her background, competence and personal learning objectives. However, no library is capable of pleasing all its users due to different constraints.

It is clear that libraries that offer full support to patrons can achieve greater user satisfaction (Ose and Esse, 2013). Through preserving and distributing a variety of sources of information related to user group needs, libraries facilitate analysis processes. The facilities and services which would be provided or expanded in a library are decided by many factors. User expectations and user retention are among the most important. User loyalty plays a crucial function in the library's growth and provisioning. For the availability of necessary materials and amenities in the library, future users' input on library resources, programmes and facilities should be considered (Sriram and Rajev, 2014). The provision of reliable services also plays a major role in the happiness of consumers.

The library is known as an information centre and an ocean of knowledge. To serve the knowledge needs of the students, it has countless tools. In the institutions where they represent, academic libraries play a significant role. Academic libraries' main aim is to help the parent organisation in achieving its goals. The support of a well-established library is important for every university system. The fundamental role of an academic library is to provide support activities for teaching, learning and study by offering appropriate and usable sources of information in a format. By having access to worldclass digital services, libraries are seen as learning organisations promoting academic and scientific practices. Since academic libraries aim to meet and fulfil their users professional needs, it is therefore necessary to know the level of their success and how well users view their services and resources (Hussein and Islam, 2012).

Review of Related Literature: Ahmad (2011) was of the view that there is an urgent need of revision of library information sources and services as per changing information environment. Bhatti (2010) revealed that libraries should build their information sources and services as per the needs of library patrons. Mahawar, Verma and Narayan (2009) conducted a study and revealed that maximum users are moderately satisfied with the services of libraries. Further authors suggested that libraries need to embrace the technological advancements to keep user services as per the recent advancements. On the other hand Nejati and Nejati (2008) revealed that libraries have had adopted "successful customer service strategies from the corporate world".
One more study conducted by Nzivo (2012) highlighted that users were unaware about the electronic resources and lack of information retrieval skills was also witnessed. Similar study was conducted by Dhanavandan, Mohammed and Nagarajan (2012) and revealed purpose of usage of electronic resources and found that library users were using electronic resources for the purpopse of research and study purposes. The study carried out earlier by Shaqouri and Daher (2010) showed that usage of electronic resources were significant among respondents. On the other hand the study of Ganaie and Rather (2014) witnessed the level of satisfaction very low among library users regarding the different sources and services.

But the results of study carried out by Pandey and Singh (2014), Motiang, Wallis and Karodia (2014) were contradictory with Ganaie and Rather (2014). The study of Idiegbeyan and Ugwunwa (2013) revealed the status of private university libraries and found that the status was to some extent up to mark. Further, suggested few things like enhancing the services and strengthen the sources part of libraries are of utmost importance. Wani, Shiekh and Jan (2019); Wani, Shafi and Sheikh (2019) found that many library users of "Allama Iqbal Library" were not aware of sources and services of library.

The studies of Gunasekera (2010); Veena and Kotari (2016); Onifade, Ogbuiyi and Omeluzor (2013) highlighted the usage, purpose and frequency of library visits of users. Further, these studies revealed the resource usage and awareness. Similarly Arshad and Ameen (2010); Padmavathi, Ningaiah and Biradar (2017); Mostofa and Hossain (2014) conducted the studies across different times and at different places. The works of these authors deliberated upon service qualities, satisfaction level of library users towards services and resources, library visiting habits and purpose.

\section{Objectives}

1. To identify the awareness among library users regarding 'resources', and 'services'.

2. To compare the differences on the awareness among the library users of selected academic libraries of JEtK.

\section{METHODOLOGY}

For achieving the objectives of current study authors used survey method. For the purpose of collection of data from sample size of 600 respondents a structured questionnaire was drafted and distributed among respondents. Sampling procedure followed by the authors was simple random sampling. The sample was selected from universities of J\&tK, two central and two state universities viz University of Kashmir, University of Jammu, Central University of Kashmir and Central University of Kashmir. For analyzing the results data was codified and tabulated in one of the widely used statistical software for social sciences research that is SPSS Software. 
Data Interpretation and Analysis

Services Awareness among Library users: Table 1 presents the mean $(\mathrm{x} \bigotimes)$, median $(\mathrm{M})$ and the standard deviation (SD) of the scores of the Individual statements to measure the awareness of users on library services. Based on the overall mean of $\mathrm{x} \bigotimes 1.92$ and M 2.00, it can be concluded that the users are well aware about the services of concerned libraries. Further it is also evident from the data that at certain services there is a negative skew, users of concerned libraries under study were slightly unaware regarding certain services.

Table 1. Services awareness among library users

\begin{tabular}{|c|c|c|c|c|c|c|c|c|c|c|}
\hline University & & CSA & CAS & PSA & RRA & ILL & OPAC & ISA & Ez-P & Overall \\
\hline \multirow[t]{3}{*}{ UOK } & Mean & 1.75 & 1.73 & 1.62 & 1.70 & 2.39 & 1.90 & 2.01 & 2.20 & 1.91 \\
\hline & Median & 2.00 & 1.00 & 1.00 & 2.00 & 3.00 & 2.00 & 2.00 & 2.00 & 1.85 \\
\hline & Std. Deviation & 0.787 & 0.858 & 0.800 & 0.702 & 0.767 & 0.749 & 0.760 & 0.769 & 0.77 \\
\hline \multirow[t]{3}{*}{ UOJ } & Mean & 1.90 & 1.84 & 1.62 & 1.70 & 2.32 & 1.90 & 1.99 & 2.11 & 1.92 \\
\hline & Median & 2.00 & 2.00 & 1.00 & 2.00 & 3.00 & 2.00 & 2.00 & 2.00 & 2 \\
\hline & Std. Deviation & .809 & .828 & .800 & .702 & .780 & .749 & .755 & .756 & 0.77 \\
\hline \multirow[t]{3}{*}{ CUK } & Mean & 1.89 & 1.92 & 1.67 & 1.78 & 2.25 & 1.90 & 2.01 & 2.15 & 1.94 \\
\hline & Median & 2.00 & 2.00 & 1.00 & 2.00 & 2.00 & 2.00 & 2.00 & 2.00 & 1.87 \\
\hline & Std. Deviation & .796 & .815 & .815 & .767 & .819 & .749 & .764 & .754 & 0.78 \\
\hline \multirow[t]{3}{*}{ CUJ } & Mean & 1.85 & 1.99 & 1.65 & 1.69 & 2.22 & 1.90 & 1.95 & 2.14 & 1.92 \\
\hline & Median & 2.00 & 2.00 & 1.00 & 2.00 & 2.00 & 2.00 & 2.00 & 2.00 & 1.87 \\
\hline & Std. Deviation & .798 & .786 & .812 & .704 & .826 & .749 & .754 & .777 & 0.77 \\
\hline \multirow[t]{3}{*}{ Total } & Mean & 1.85 & 1.87 & 1.64 & 1.72 & 2.29 & 1.90 & 1.99 & 2.15 & 1.92 \\
\hline & Median & 2.00 & 2.00 & 1.00 & 2.00 & 3.00 & 2.00 & 2.00 & 2.00 & 2 \\
\hline & Std. Deviation & .798 & .826 & .805 & .719 & .799 & .747 & .757 & .763 & 0.77 \\
\hline
\end{tabular}

Note: University of Kashmir (UOK), University of Jammu (UOJ), Central University of Kashmir (CUK), Central University of Jammu (CUJ), Circulation Service Awareness (CSA), Current Awareness Service (CAS), Photocopying Service Awareness (PSA), Reading Room Service Awareness (RRA), Inter library Loan Service Awareness (ILL), Online Public Access Catalogue Awareness (OPAC), Internet Service Awareness (ISA), Ez-Proxy Service Awareness (Ez-P), Reference Books Awareness (RBA), Electronic Resources Awareness (ERA), Newspapers and Magazines Awareness (NMA), Journal Indexes and Abstracts Awareness (JIA), Audio Visuals Awareness (AVA),Journals Awareness (JA)

Table 2. Resource awareness among library users

\begin{tabular}{|l|c|c|c|c|c|c|c|c|}
\hline \multirow{3}{*}{ University } & & RBA & ERA & NMA & JIA & AVA & JA & Overall Mean \\
\hline \multirow{3}{*}{ UOK } & Mean & 1.98 & 1.98 & 2.01 & 2.15 & 1.99 & 1.94 & 2.01 \\
\cline { 2 - 9 } & Median & 2.00 & 2.00 & 2.00 & 2.00 & 2.00 & 2.00 & 2.00 \\
\cline { 2 - 9 } & Std. Dev. & .764 & .773 & .764 & .730 & .728 & .762 & 0.75 \\
\hline \multirow{3}{*}{ UOJ } & Mean & 1.82 & 1.77 & 1.84 & 2.07 & 1.99 & 1.86 & 1.89 \\
\cline { 2 - 9 } & Median & 2.00 & 2.00 & 2.00 & 2.00 & 2.00 & 2.00 & 2.00 \\
\cline { 2 - 9 } & Std. Dev & .786 & .839 & .795 & .769 & .847 & .795 & 0.81 \\
\hline \multirow{3}{*}{ CUK } & Mean & 1.74 & 1.65 & 1.98 & 1.92 & 1.70 & 1.93 & 1.82 \\
\cline { 2 - 9 } & Median & 2.00 & 2.00 & 2.00 & 2.00 & 1.00 & 2.00 & 1.83 \\
\cline { 2 - 9 } & Std. Dev & .806 & .696 & .798 & .782 & .792 & .766 & 0.77 \\
\hline \multirow{3}{*}{ CUJ } & Mean & 1.81 & 1.83 & 1.73 & 1.91 & 1.69 & 2.22 & 1.86 \\
\cline { 2 - 9 } & Median & 2.00 & 2.00 & 2.00 & 2.00 & 1.50 & 2.00 & 1.92 \\
\cline { 2 - 9 } & Std. Dev & .766 & .766 & .791 & .772 & .777 & .732 & 0.77 \\
\hline \multirow{3}{*}{ Total } & Mean & 1.84 & 1.81 & 1.89 & 2.01 & 1.85 & 1.99 & 1.90 \\
\cline { 2 - 9 } & Median & 2.00 & 2.00 & 2.00 & 2.00 & 2.00 & 2.00 & 2.00 \\
\cline { 2 - 8 } & Std. Dev & .784 & .778 & .793 & .769 & .799 & .774 & 0.78 \\
\hline
\end{tabular}


Table 3. Service Awareness by University (One way Annova)

ANOVA

\begin{tabular}{|c|c|c|c|c|c|c|}
\hline & Sum of Squares & Df & Mean Square & $\mathrm{F}$ & Sig. & \\
\hline \multirow[t]{3}{*}{ CSA } & Between Groups & 2.258 & 3 & 0.753 & 1.184 & 0.315 \\
\hline & Within Groups & 378.94 & 596 & 0.636 & & \\
\hline & Total & 381.198 & 599 & & & \\
\hline \multirow[t]{3}{*}{ CAS } & Between Groups & 5.632 & 3 & 1.877 & 2.776 & 0.041 \\
\hline & Within Groups & 402.967 & 596 & 0.676 & & \\
\hline & Total & 408.598 & 599 & & & \\
\hline \multirow[t]{3}{*}{ PSA } & Between Groups & 0.293 & 3 & 0.098 & 0.15 & 0.93 \\
\hline & Within Groups & 387.947 & 596 & 0.651 & & \\
\hline & Total & 388.24 & 599 & & & \\
\hline \multirow[t]{3}{*}{ RRA } & Between Groups & 0.765 & 3 & 0.255 & 0.492 & 0.688 \\
\hline & Within Groups & 308.633 & 596 & 0.518 & & \\
\hline & Total & 309.398 & 599 & & & \\
\hline \multirow[t]{3}{*}{ ILL } & Between Groups & 2.547 & 3 & 0.849 & 1.332 & 0.263 \\
\hline & Within Groups & 379.827 & 596 & 0.637 & & \\
\hline & Total & 382.373 & 599 & & & \\
\hline \multirow[t]{3}{*}{ OPAC } & Between Groups & 0 & 3 & 0 & 0 & 1 \\
\hline & Within Groups & 334 & 596 & 0.56 & & \\
\hline & Total & 334 & 599 & & & \\
\hline \multirow[t]{3}{*}{ ISA } & Between Groups & 0.325 & 3 & 0.108 & 0.188 & 0.904 \\
\hline & Within Groups & 342.633 & 596 & 0.575 & & \\
\hline & Total & 342.958 & 599 & & & \\
\hline \multirow[t]{3}{*}{ Ez-P } & Between Groups & 0.593 & 3 & 0.198 & 0.339 & 0.797 \\
\hline & Within Groups & 347.907 & 596 & 0.584 & & \\
\hline & Total & 348.5 & 599 & & & \\
\hline
\end{tabular}

Table 4. Comparison of resource awareness among users by concerned university

ANOVA

\begin{tabular}{|l|c|c|c|c|c|c|}
\hline \multirow{4}{*}{ RBA } & & Sum of Squares & df & Mean Square & F & Sig. \\
& Between Groups & 4.66 & 3 & 1.553 & 2.548 & 0.055 \\
\cline { 2 - 7 } & Within Groups & 363.333 & 596 & 0.61 & & \\
\cline { 2 - 7 } & Total & 367.993 & 599 & & & \\
\hline \multirow{4}{*}{ ERA } & Between Groups & 8.645 & 3 & 2.882 & 4.858 & 0.002 \\
\cline { 2 - 7 } & Within Groups & 353.54 & 596 & 0.593 & & \\
\cline { 2 - 7 } & Total & 362.185 & 599 & & & \\
\hline \multirow{4}{*}{ NMA } & Between Groups & 7.313 & 3 & 2.438 & 3.933 & 0.009 \\
\cline { 2 - 7 } & Within Groups & 369.427 & 596 & 0.62 & & \\
\cline { 2 - 7 } & Total & 376.74 & 599 & & & \\
\hline & Between Groups & 6.493 & 3 & 2.164 & 3.713 & 0.011 \\
\cline { 2 - 7 } & Within Groups & 347.4 & 596 & 0.583 & & \\
\hline & Total & 353.893 & 599 & & & \\
\hline \multirow{3}{*}{ AVA } & Between Groups & 13.205 & 3 & 4.402 & 7.102 & 0.000 \\
\cline { 2 - 7 } & Within Groups & 369.38 & 596 & 0.62 & & \\
\cline { 2 - 7 } & Total & 382.585 & 599 & & & \\
\hline \multirow{2}{*}{ JA } & Between Groups & 11.325 & 3 & 3.775 & 6.473 & 0.000 \\
\cline { 2 - 7 } & Within Groups & 347.593 & 596 & 0.583 & & \\
\cline { 2 - 7 } & Total & 358.918 & 599 & & & \\
\hline
\end{tabular}


Resource awareness among library users: Table 2 presents the mean $(x \otimes)$, median $(M)$ and the standard deviation (SD) of the scores of the Individual statements to measure the awareness of users on library services. Based on the overall mean of $\mathrm{x} \bigotimes 1.90$ and $\mathrm{M} 2.00$, it can be concluded that the users are well aware about the resources of the concerned libraries. The in-depth analysis of data showed that the mean $x \bigotimes=1.92$ was slightly lower than the median $M=2.00$ ), signifying a slight negative skew.

Comparison of mean scores of services of the libraries: Table 3 presents the mean awareness scores on the services of the libraries by selected universities under scope of present study. One way Annova was used for gauging mean tests. It is evident from the results that only CAS awareness and OPAC awareness were statistically significant $(p<0.05)$, the exact observed value of CAS $(p=0.041<0.05)$ and OPAC $(p=.00<0.05)$. There it can be concluded that the there was a significant difference in awareness of CAS and OPAC within the users of all four University Libraries that is UOK, UOJ, CUK, and CUJ $[F(3,596)=2.77, p=0.041] ;[F(3,596)=0.00, p=$ 1 ] respectively. The rest services like CSA, PSA, RRA, ILL, ISA, and Ez-P showed the insignificant difference in such a way the $\mathrm{p}$ value for $\mathrm{CSA}=0.315$, $\mathrm{PSA}=0.93$, $\mathrm{RRA}=0.688, \mathrm{ILL}=0.263, \mathrm{ISA}=0.904, \mathrm{Ez}-\mathrm{P}=0.79$. Comparison of resource awareness among users by
concerned university: Table 4 presents the mean comparison of resource awareness among users of the libraries by universities under the scope of present study. One way Annova was used for gauging mean comparisons. It is evident from the results that all the resource awareness parameters were statistically significant excluding RBA having $\mathrm{P}$ value greater than $0.05(p=0.055>0.05)$. The significant difference was present so far as awareness of diverse resources among respective users of concerned libraries are concerned. It can be concluded that there was a vivid difference in awareness of resources between and within universities (from which sample was taken).

\section{DISCUSSION AND CONCLUSION}

University libraries are vital organs for universities to support academics and research related activities .Effective use of resources and services of any academic library particularly university libraries will enhance the research and academic tasks. The efficiency of academic library depends upon the awareness and familiarity of the users with different services and resources of libraries. The author also supports the statement that more the familiarity more the usage of services and resources. Library services and resources support the overall development of the apprehension of the "university curriculum and research activities". Therefore the present study focused on awareness of services and resources of the university libraries of four selected universities that is UOK, UOJ, CUK, and CUJ.

Present era is the digital era there are lots of innovations in every sector. Therefore, libraries too should embrace the innovations and should provide services to the end users as per the latest advancements. An investment is vital in technological aspects to bring change in the system. By strengthening decision-making, expediting solutions and eliminating needless testing, access to information yields both time and cost savings. To help understand how effective or efficient the library is, assessment of library resources is important. Assessment aims to improve the standards of organisations. Therefore, in order to assess the precise needs of the clientele, it has become necessary to regularly access the information sources, information services and information needs and enjoyment of library users.

\section{REFERENCES}

Ahmad, S. (2011). Information seeking behaviour of the forestry scientists of the Pakistan Forest institute, peshawar. (M.Phil thesis) University of the Punjab, Lahore, Punjab.

Arshad, A., and Ameen, K. (2010). Service quality of the University of the Punjab's libraries. Performance Measurement and Metrics, 11 (3), 313-325. doi: https:// doi.org/10.1108/14678041011098578

Bhatti, R. (2010). An evaluation of user-education programs in the university libraries of Pakistan. Library Philosophy and Practice.

Dhanavandan, S., Mohammed, E. S., and Nagarajan, M. (2012). Access and Awareness of ICT Resources and Services in Medical College Libraries in Puducherry. Library Philosophy and Practice (e-journal). Retrieved from http://digitalcommons.unl.edu/libphilprac/750

Ganie, S.A., and Rather, M.K. (2014). Information seeking behavior among PG students of University of Kashmir: An analytical Study. Journal of Advancements in Library Sciences. 1(1). Retrieved from: https://www. researchgate.net/publication/267261285.

Gunasekera, C. (2011). Students usage of an Academic Library: A user survey conducted at the main library University of peradeniya. Journal of University Librarians Association of Sri Lanka. 14(1). Retrieved from: http://jula.sljol.info.

Hussain, H. (2013). The ICT based library and information services: A case study of business schools in Delhi and NCR region. Library Philosophy and Practice. Retrived from: http://digitalcommons.unl.edu/libphilprac/1011 Idiegbeyan-ose, J and Esse, U.C. (2013). Students satisfaction with Academic Library Resources And Services: The Covenant University Library Experience. Journal of Information And Knowledge Management. 4(1). Retrieved from: http://eprints.covenantuniversity. edu.ng/2404

Mahawar, K.L., Verma, S. and Narayan, R. (2010). Library Services Vis-À-Vis Satisfaction among Students of Tagore Library, University of Lucknow: A Study. Srels Journal Of Information Management. 47(2), 155162. Retrieved from: http://crl.du.ac.in/ical09/papers/ index_files/ical-115_131_289_3_RV.pdf

Mostafa, M.S . K., and Hossain,.U.M. D. (2014). 
Student's perceptions of library services in Academia of Bangladesh: A case study of Rajshahi University. International Journal of Research In Humanities , Arts and Literature, 2(8),81-90. Retrieved from www. impactjournals.us

Motiang, I. P, Wallis, M. and Karodia, A. M. (2014). An evaluation of user satisfaction with library services at the University of Limpopo, Medunsa campus (Medical University of Southern Africa. Arabian Journal of Business and Management Review, 3(11). Retrieved from www.arabianjbmr.com

Nejati, M., and Nejati, M. (2008). Service quality at University of Tehran Central Library. Library Management. 29(6/7), 571-582. doi: https://doi. org/10.1108/01435120810894563

Nzivo, C.N. (2012). User perception on library services and information resources in Kenyan Public Libraries. Library Review. 61(2), 110-127. doi: https://doi. org/10.1108/00242531211220744

Onifade, N. F., Ogbuiyi, U. S. and Omeluzor, U.S. (2013). Library resources and service utilization by postgraduate students in a Nigerian private university. International Journal Of Library and Information Science. 5(9), 291293.

Ose, J. \&t Esse, U. (2013). Students Satisfaction with Academic Library Resources and Services: The Covenant University Library Experience. Journal of Information and Knowledge Management. 4(1). Retrieved from: http://eprints.covenantuniversity.edu.ng/2404 Padmavathi, N., Ningaiah, A. and Birada, K. (2017). Use and User satisfaction of Library Resources and Services by PG Students and Research Scholars in Bangalore University Library, Bangalore. Journal Of Library \&
Information Science. 7(1), 116-118. Retrieved from www. irjlis.com

Pandey, S.K. and Singh, M.P. (2014). Users satisfaction towards library resources and services in Government Engineering Colleges of Guru Gobind Singh Indraprastha University, Delhi: An Evaluative Study. Journal of Library, Information and Communication Technology. 6 (1-2). Retrieved from: www.escienceworld.org Shaqour A. and Daher W. (2010). Factors Influencing Students' Use of Electronic Resources and their Opinions about this Use: The Case of Students at An-Najah National University. International Journal of Emerging In Learning. 5 (4). DOI: https://doi.org/10.3991/ijet. v5i4.1424

Sriram, B. and Rajev, M.K.G. (2014). Impact of Academic Library Services On User Satisfaction: Case study of Sur University College, Sultanate of Oman. DESIDOC journal of Library \& Information Technology, 34(2),140-146. Retrieved from https://publications.drdo.gov.in./ojs/ index.php/djlit/article/view/4499

Veena, G., and Kotari, P.N. (2016). User satisfaction with Library Resources, Services and facilities: A study in SDM college library, Ujre. Indian Journal Of Information Sources and Services. 6(1), 1-4. Retrieved from www. trp.org.in

Wani, J.A., Shiekh, H.A and Jan, S. (2019). The Resources of Allama Iqbal Library: An Evaluative Study. Library Philosophy and Practice (e-journal). 2733. Availabe at: https://digitalcommons.unl.edu/libphilprac/2733

Wani, J. Shafi, I, and Sheikh, H.A. (2019). Satisfaction of Users with the Services of Allama Iqbal Library. Library Philosophy and Practice (e-journal). 2730. Available at: https://digitalcommons.unl.edu/libphilprac/2730 